\title{
Is sustainable development of scientific systems possible in the neo-liberal agenda?
}

\author{
Vladimir M. Moskovkin, Olesya V. Serkina* \\ Belgorod State University, 85 Pobedy St., Belgorod 308015, Russia
}

\begin{abstract}
This paper discusses the evolution of large scientific systems in general and the system of formal scientific communications in particular in the context of their gradual transition to private hands. This in turn results in increased 'phony' research fronts, fueled by the interests of big business, pools of inaccessible hi-impact Anglo-American journals whose authors cite each other (author's citation cartels), and non-transparent global university rankings, which can be manipulated. Furthermore, the authors argue that the functioning of national scientific systems by means of having them linked to the global system of formal scientific communications and rankings is organized as an unrestrained race for publications, citations, impact factors, and rankings in which strong systems only get stronger and the weak ones get weaker. Such a race therefore cannot lead to sustainable development of the scientific system. The authors also look at the feudalism of knowledge and identify 3 steps to oppose this process.
\end{abstract}

KEY WORDS: Scientific systems - Sustainable development $\cdot$ Neo-liberal agenda $\cdot$ Formal scientific communications $\cdot$ Knowledge feudalism $\cdot$ Open Access

\section{EVOLUTION OF THE SYSTEM OF FORMAL SCIENTIFIC COMMUNICATIONS AND ITS DRAWBACKS}

In this article, a country's scientific system is viewed as a set of subsystems of production, evaluation, dissemination, and consumption of scientific knowledge within that country.

National scientific systems began to develop vigorously after an exchange of knowledge had been organized among them. Since the mid-17th century, when the first scientific journals appeared, this bridging role between the production and consumption subsystems has been fulfilled by a system of formal scientific communications (dissemination subsystem), which has survived to the present day. The formal scientific communication system (modern scientific periodicals) was created in 1665 with the publication of Philosophical Transactions and the Journal des Sçavans, and as a medium of communication, modern scientific periodicals are the lifeblood of the

*Corresponding author: serkina@bsu.edu.ru advancement of science (Shank 1962). At the end of the 17 th century, approximately 30 science and medicine journals had been created (Porter 1964). In the review 'A short history of science writing' (Scitext Cambridge 2000), the author states 'Several dozen more scientific journals were published in the remainder of 17 th century, and hundreds more were launched in the next (especially in Germany), a survey has uncovered some 750 titles to 1800 . Only 50 years further on there were several thousand, as the 19th century saw an explosion in their number'. According to anther source, the number of scientific journals from 1800 to 1900 increased from 100 to 10000 (Price 1963). The number and extent of the growth of scientific periodicals can only be surmised from evidence such as the increase in the number of titles in the World List of Scientific Periodicals; for example, from 25000 in 1921 to 50000 in 1950 (Shank 1962). At present, on the SCImago platform one can find approximately 23000 SCOPUS journals. All of the above is summarized in Table 1.

() The authors 2016. Open Access under Creative Commons by Attribution Licence. Use, distribution and reproduction are unrestricted. Authors and original publication must be credited. 
Table 1. Evolution of the system of formal scientific communications

\begin{tabular}{|c|c|c|}
\hline Year & Number of journals & Subject area \\
\hline 1700 & Tens of journals & Natural Philosophy, medicine \\
\hline 1800 & Hundreds of journals & $\begin{array}{l}\text { Dozens of subject areas: natural philosophy, medicine, mathematics, astronomy, } \\
\text { physics, chemistry, geography, botany, zoology, physiology }\end{array}$ \\
\hline 1900 & Thousands of journals & $\begin{array}{l}\text { Tens of subject areas. For example, physics at first divided into general and ex- } \\
\text { perienced, then into subject areas, such as electrodynamics, thermodynamics, etc.; } \\
\text { geography first divided into political, mathematical and physical, and in the late } \\
\text { 19th century the latter generated meteorology, climatology, geomorphology, } \\
\text { glaciology, biogeography, soil science, etc. }\end{array}$ \\
\hline 2000 & $\begin{array}{l}\text { Tens of thousands of journals } \\
(\sim 23000 \text { journals at SCImago } \\
\text { platform) }\end{array}$ & $\begin{array}{l}\text { Hundreds of specialized subject areas, as well as inter-disciplinary areas, con- } \\
\text { nected with the development of systems analysis and synergetics (over } 300 \text { subject } \\
\text { categories at SCImago platform) }\end{array}$ \\
\hline
\end{tabular}

Specialization of the subject matter of scientific journals began in the mid-18th century, medical science leading the way (Scitext Cambridge 2000). Naturally, growth of science at its initial stage led to its specialization, and consequently to splitting of older journals and the creation of new ones. According to Benjamin (1958, personal interview), 'when the number of practitioners in any field of science reaches about 10000 , areas of specialization naturally occur in the field, and in fact, bifurcation may create entirely new fields of science, (cited in Shark 1962, p. 400). The contemporary format of the formal scientific communication system is shown in Fig. 1 (Moskovkin 2012).
In the 17th-19th centuries, the cores of national scientific systems were universities and scientific societies, which published scientific journals. In the 20th century, the system of formal scientific communication began to gradually move from the scientific community to the hands of private capital, and is currently controlled by some major commercial publishers (Elsevier, Springer, Wiley, etc.) with all of the analytics accompanying the journal publishing business also under control of private capital (Stage 1, Fig. 1). Indeed, the Institute for Scientific Information (founded in 1960) was first acquired by Thomson in 1992, which later merged with Reuters Company in

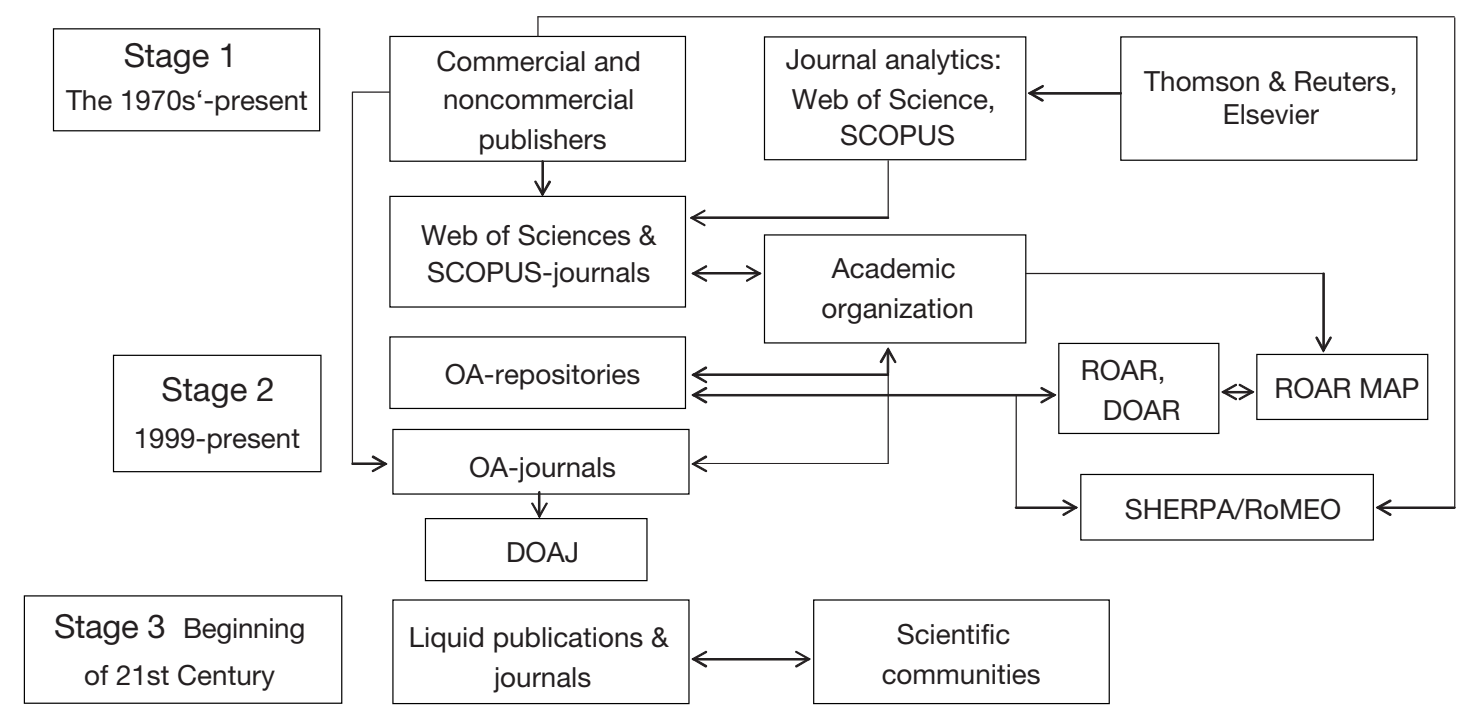

Fig. 1. Structure of the formal scientific communication system. ROAR: Registry of Open Access Repositories (roar. reprints.org), belongs to the University of Southampton and contains the main characteristics of the registration and capacity of over 3900 Open Access (OA) repositories; DOAR: Directory of Open Access Repositories (opendoar.org), belongs to the University of Nottingham and contains data about over 2600 OA repositories; SHERPA/RoMEO: Publisher Copyright Policies \& Self-archiving (sherpa.ac.uk/romeo), belongs to the University of Nottingham and contains data about over 1800 publisher policies; ROAR MAP: Registry of Open Access Repositories Mandatory Archiving Policies (roarmap.eprints.org), belongs to the University of Southampton and contains data about over 650 policies; DOAJ: Directory of Open Access Journals (doaj.org), belongs to Lund University and contains data about over 10000 OA journals 
2008 to form Thomson-Reuters, the largest media holding company, now controlling $30 \%$ of the global media market. Shortly after the merger, the new company, with headquarters in New York, had annual revenues of $\$ 12.5$ billion, 50000 employees and more than 40000 customers in 155 countries (Haycock \& MacMillan 2008). This media holding is currently responsible for all of the analytics of the global representative scientific information flow in the form of paper citation indices, journal impact factors and other indicators. The second most important information-analytical system SCOPUS belongs to the world's largest commercial publisher of scientific periodicals, Elsevier.

Thus, all the processes to assess and disseminate new knowledge have been controlled by the neo-liberal forces represented by transnational capital and commercial publishers of scientific periodicals. The same can be said about producing research breakthroughs, which are heavily supported by transnational capital. The dominant role of this capital in the dissemination of knowledge and the formation of scientific trends could only lead to a crisis within the system of formal scientific communications. Deep within academic and library communities, this crisis, connected with very expensive subscriptions to scientific journals in the late 20th-early 21st centuries, caused a powerful movement to support open access to scientific knowledge. According to G. Monbiot, the average cost of an annual subscription to scientific journals can range from $\$ 3000-4000$ to $\$ 10000$ a year, while the most expensive one-Elsevier's Biochimica et Biophysica Acta - is \$20930 (Monbiot 2011). This brings astronomical profits to publishing houses, 3 of which - Elsevier, Springer and Wiley-have become the major players in the market of scientific journals, with a share of $42 \%$ of all research articles published (McGuigan \& Russel 2008). This has started to somehow change the system of formal scientific communications, complementing it with repository subsystems and open access journals, but the role of the core system in the form of traditional journals included in the Web of Science and SCOPUS databases has remained unchanged (Stage 2, Fig. 1). This system is responsible for numerous 'phony' research fronts, fu- eled by the interests of big business, pools of inaccessible hi-impact Anglo-American journals whose authors cite each other (author citation cartels; Franck 1999, Wallace et al. 2012), and non-transparent global university rankings, which can be manipulated (Balatsky \& Ekimova 2012, Robinson 2014, Stergiou \& Lessenich 2014).

The functioning of national scientific systems by means of having them linked to the global system of formal scientific communications and rankings is organized as an unrestrained race for publications, citations, impact factors, ratings and innovation, in which strong systems only become stronger and the weak systems become weaker. So it would be wrong to talk about sustainable development of scientific systems in the context of a neo-liberal agenda and globalization (Fig. 2). This race has even coined a catchy but cynical slogan-'publish or perish'which means that instead of thinking and doing quality research, a scientist has to write more articles and have them published. Strictly speaking, Fig. 2 illustrates the following: national research systems supported mainly from national budgets (when entering the global system of evaluation and dissemination of research results, which is in turn controlled by transnational companies and large commercial publishers) automatically fall under the influence of the neo-liberal agenda and the 'publish or perish' ideology, which leads to the 5 above-

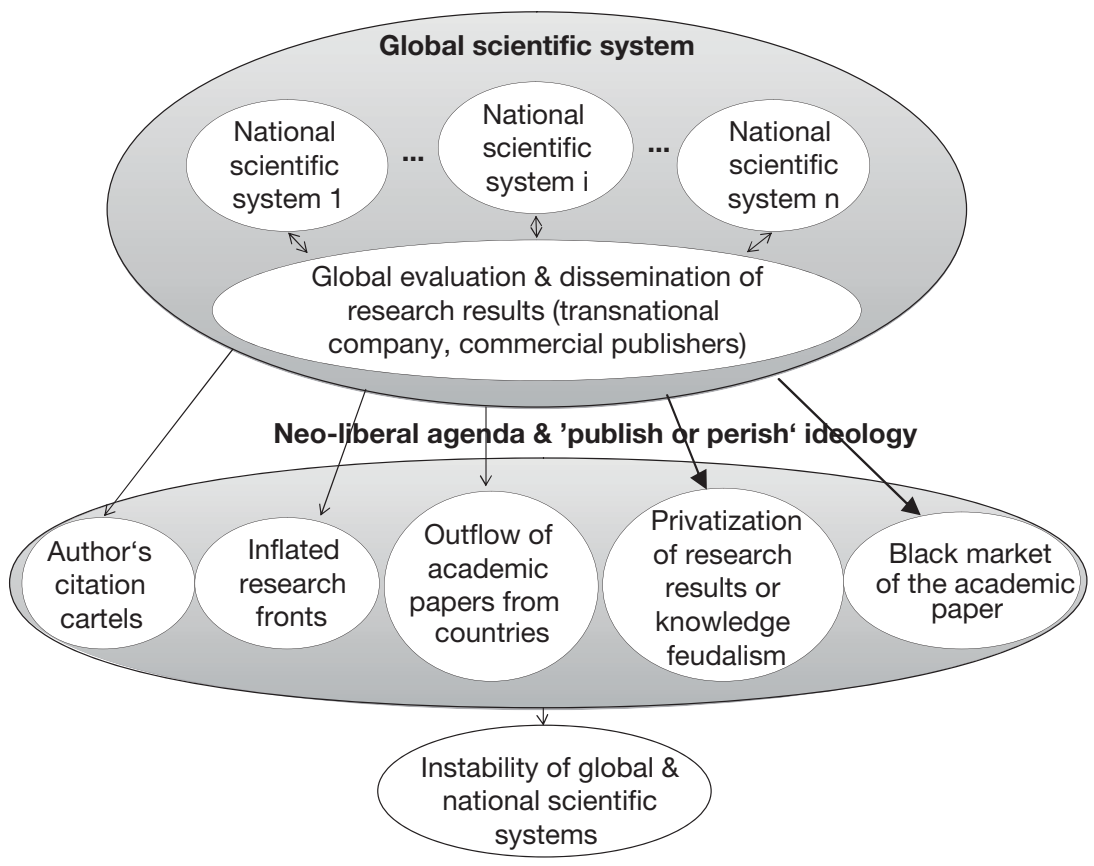

Fig. 2. Movement of the global scientific system towards instability in the environment of the neo-liberal agenda and 'publish or perish' ideology 
mentioned (this paragraph) flawed practices and processes, and thus to the instability of global and national scientific systems.

Now Russia as well as France has joined this race. The President of Russia has set the task for the top 5 Russian universities to enter the top 100 leading global university rankings by 2017 and for the share of Russian publications in the global publication flow to be increased to $2.44 \%$ (Inozemtsev 2014). The French President wants to see 10 top national universities among the top 100 world university centers (Coughlan 2014).

China is a shining example of what this race can lead to, as the market of fake publications in China in 2009 amounted to 150 million dollars (a 5-fold increase compared with that of 2007), and every third Chinese researcher now plagiarizes, falsifies research findings and forges data (Qiu 2010). The reason for such malpractice may be the desire for quick success and short-term benefits, among the latter being various awards, bonuses or privileges for having a paper published in internationally recognized journals (Qiu 2010). The Chinese university monetary rewards systems (Shao \& Shen 2011) should be held responsible not only for creating the market of fake publications (Qiu 2010), but also for taking quality academic papers out of the national scientific system (Shao \& Shen 2011) (Fig. 2). operating profit margin of $36 \%$ (The Economist 2011). One can add here Open Access options that some publishers offer to authors, expecting the latter to pay up to $\$ 3000$ on average, though the ultimate burden will indirectly be still placed on taxpayers. In other words, the state paid scientists for creating new knowledge, and then it paid again by giving money to research libraries so that other scientists could learn about this new knowledge. This is nonsense, taken by everyone as guidance. But why is this happening? It is because of the activity of other organizations parasitizing scientific knowledge: organizations which have launched and serviced the publication race ('publish or perish'). Acting in collusion with state organizations, they have long decided that the career growth of a scientist depends exclusively on his or her articles published in high-impact journals. Everyone is excited about this, the journals' impact factors, the Hirsch index, university rankings and other signs of this race. But if you add here transnational technological corporations, which buy for comparatively little money the copyrights to fundamental knowledge that has already been published in scientific journals and has been paid for through taxpayers' money, you will not be able to imagine the real scale of the fraud. Thus, it is reasonable to expect that if a state allocates money for generating new knowledge, it should be responsible for its monitor-

\section{THE CIRCLE OF PRODUCTION, DISTRIBUTION AND CONSUMPTION OF SCIENTIFIC INFORMATION}

Let us discuss the mechanisms of privatizing research results or knowledge feudalism (Fig. 3), based on Kiley \& Terry (2006), Herb (2010) and Monbiot (2011). Today, governments around the world allocate considerable funds to research, encouraging scientists to generate new knowledge and publish their findings in internationally acclaimed journals, whereas private publishers, who have long monopolized the market of scientific periodicals, have been sucking out huge amounts of money from state budgets for the distribution of journals or articles, and recently have been taking huge amounts of money from scientists as well (Monbiot 2011). For example, in 2010 Elsevier made $\$ 1.1$ billion of revenues, which included its

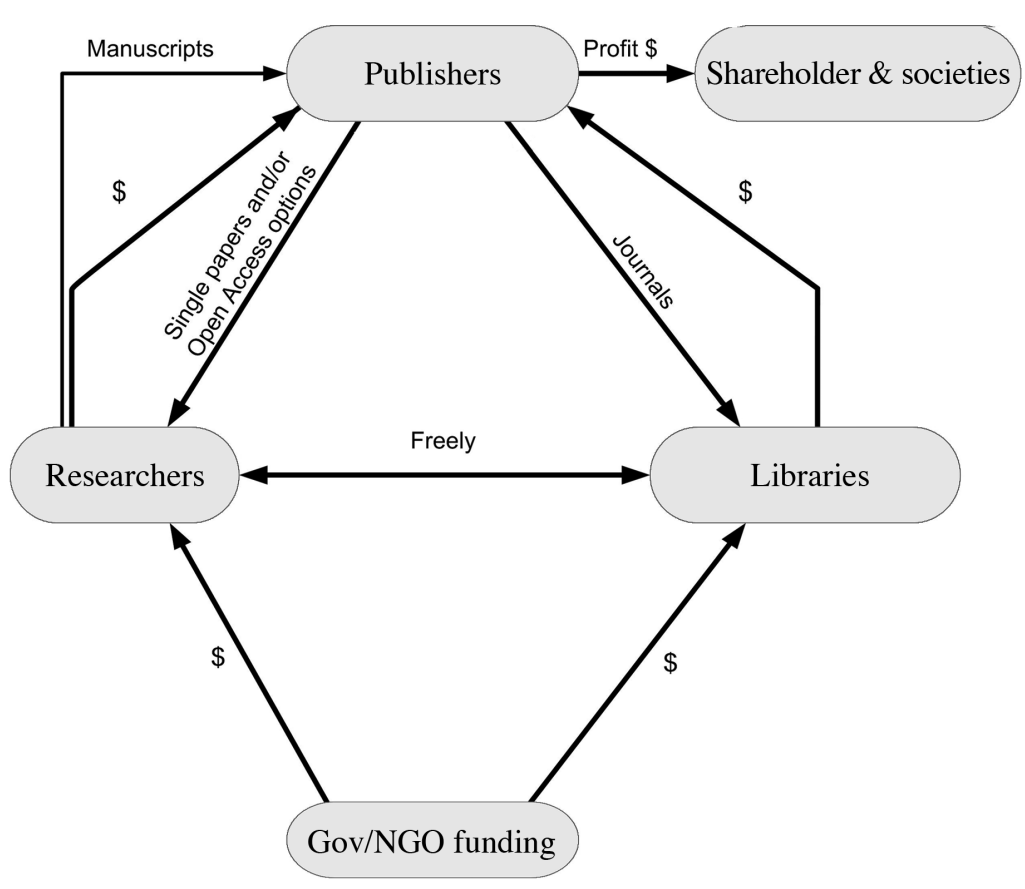

Fig. 3. Circle of production, distribution and consumption of scientific information (based on Kiley \& Terry 2006, reprinted in Herb 2010) 
ing, assessment and distribution. As a result, if we end this 'publish or perish' race based on the impact factor of journals, then the above-mentioned scheme of publishers' obtaining super profits (see Fig. 3) will collapse at once, as the flow of articles submitted to elite journals will decrease because of the availability of many other journals, and libraries will stop subscribing to super expensive elite journals. We have borrowed the scheme shown in Fig. 3 from Kiley \& Terry (2006; reprinted in Herb 2010) and improved it by adding material (manuscripts, journals, single papers) and financial (payments to scientists for single papers, payments for Open Access options) flows.

Using the Google Books browser, we can see that the 'publish or perish' motto was first introduced at Harvard University, presumably by Harvard President James Conant. The appearance of this imperative was viewed then as 'a vengeance into America's oldest universities', though even the oldest British universities, being rather skeptical about GermanAmerican academic initiatives, adopted them right away in terms of using the 'publish or perish' approach (Impressions on American Universities 19391').

The question of how this motto had appeared was also of interest to E. Garfield (1996), the founder of the Institute for Scientific Information (USA) and SCI (Science Citation Index). His investigation brought him to Marshall McLuhan's letter to poet Ezra Pound dated 22 June 1951, in which the former gave a disparaging description of the then scientific system, contemptuously referring to universities as 'beaneries':

The beaneries are on their knees to these gents [foundation administrations]. They regard them as Santa Claus. They will do research on anything that Santa Claus approves. They will think his thoughts as long as he will pay the bill for getting them before the public signed by the professory-rat. 'Publish or Perish' is a beanery motto (Garfield 1996, Letters of Marshall McLuhan 1987).

Some researchers believe that this term was quite often used by various academics in pre-war times. But no matter who coined this motto first over sixty years ago, the essence behind it hits the bull's eye today.

\section{NEW PARADIGM OF THE FORMAL SCIENTIFIC COMMUNICATION SYSTEM}

The experience of China, the second highest global player in the field of publication activity after the United States, shows that the much-vaunted system

1Published in 1939 in The Fortnightly, Vol. 152, p. 211 (no authors shown) of assessing the quality of scientific publications, which has been in existence for over 350 years, is unable to perform its functions any longer. Due to this, as well as to the fact that the current system of formal scientific communications generates a lot of information noise that distracts a researcher from intellectual activity, a few years ago the scientific community came up with a new paradigm of the formal scientific communication system called 'Liquid Publications' (research*eu 2010) (stage 3, Fig. 1). One of the ideologists of this paradigm, Fabio Casati (the University of Trento, Italy) says:

Scientists spend too much time on both having their papers published and digesting heaps of scientific papers written by their peers, thus hardly having any time to do their own research (research* eu 2010, p. 34)

Casati further notes that the benefit from liquid publications is a dramatic decrease in the number of articles, most of which record only some slight increment of knowledge. Therefore, the proponents of this paradigm suggest getting different versions of the same article published. In addition, they suggest that the process of peer review should be substituted by an indirect evaluation from a relevant scientific community that is implicity given while editing, reading and commenting on liquid journals. Fabio Casati (research*eu 2010, p. 35) explains:

If you and I accept an article to be published in our magazine, we evaluate it. When hundreds of people like us do it, we use the whole community's selective power to assess the scientific input, which will help interesting articles get above the noise.

If this paradigm is accepted by the scientific community, then, in our opinion, several problems will arise: introducing a bibliographic standard for liquid publications, their categorization (as primary and secondary papers, etc.), creating a register (directory of liquid publications) and a protocol for collecting metadata of such publications (protocol metadata harvesting of liquid publications). In this context, it is vital to prevent this process from being overly bureaucratized and to keep it within the activity and initiatives of the scientific community because as soon as big money steps in, the whole thing will be put to an end.

\section{KNOWLEDGE FEUDALISM AND HOW TO PREVENT IT}

Since the beginning of the 20th century, neoliberal thinkers have been imposing the idea that knowledge is not a public good, and it should be commercialized as soon as possible (Veblen 1918). 
Therefore, either gradually through acts of government (e.g. Bayh-Dole Act 1980, USA) or through university-private partnership, knowledge is going into private hands, and gaining incredibly in price. The leading role in the privatization of knowledge is now being played by gene patents and research on stem cells, both currently being hotly debated worldwide (Mirowski 2011). According to Mirowski (2011, p. 7), 'Much of the modern commercialization of science and the "commodification" of universities have been written on the script proclaimed by neo-liberal thinkers.' Further, he reinforces this idea by saying: 'Commercialization of science is a planned and coordinated effort of those associated with the neo-liberal agenda and that this commercialization weakens the American scientific hegemony.'

Thus, the government of the USA, having handed the key scientific policy levers over to neo-liberal forces, is no longer able to control the development of the national scientific system. But this very neo-liberal path of development of science and higher education is now being globally imposed. Talking about higher education, Mirowski uses an apt term: 'Disneyfication of higher education'. And this is what we actually see when our universities turn into show venues, where students' 'socializing' and entertainment are of much higher priority than hard work in libraries and meticulous research.

In spite of all the apparent advantages of the international Open Access movement, it turns out that in the long term Open Access strengthens the ground of knowledge feudalism or the privatization of knowledge, as under these conditions, neo-liberals (for example, powerful transnational companies and their think tanks) find it easier first to identify fundamental breakthroughs in knowledge and withdraw them from open scientific use, and then reintroduce them in unrestricted trade turnover under TRIPS (Trade-Related Aspects of Intellectual Property Rights), where this commercialized knowledge is sold at exorbitant prices (Fig. 4). This phenomenon is called the Open Access paradox (Moskovkin 2011), but it can also be called an Open Access trap. One should also remember that one of the first Open Access initiatives - the Budapest Open Access Initiative-was launched by the Open Society Institute of George Soros, one of the most famous neoliberals. Thus, one can assume that although born within scientific and library communities, the Open Access movement may be gradually falling under the latent control of neo-liberal forces.

Close contradictory connections between Open Access and information poverty have been analyzed by Jutta Haider and David Bawden (Haider \& Bowden 2006, 2007) and Ulrich Herb (2010). Admitting the existing 'hierarchical stratification' between developing and western countries, Herb (Herb 2010) argues that:

If open access is conceptualized as a vehicle to reduce the digital device, it also reinforces the existing dependencies and asymmetric allocations of discursive, political and materialistic powers (Herb 2010).

Further, Herb emphasizes 'a strong underrepresentation of scientists and scientific information from developing countries and their exclusion from scientific discourse' (Herb 2010), but he doubts that Open Access will help 'really liberate scientific communication', as he believes the only outcome from Open Access is an increased 'quantity of scientific information from developing countries' (Herb 2010).

The idea of knowledge feudalism was substantially explained in a book written by Australian scientists P. Drahos and J. Braithwaite (Drahos \& Braithwaite 2002 , p. 2-3). The authors draw parallels between medieval feudalism and information feudalism in the sphere of property rights, saying:

The redistribution of property rights in the case of information feudalism involves a transfer of knowledge assets from the intellectual commons into private hands. These hands belong to media conglomerates and integrated life sciences corporations rather than individual scientists and authors. The effect of this [...] is to raise levels of private monopolistic power to dangerous global heights.

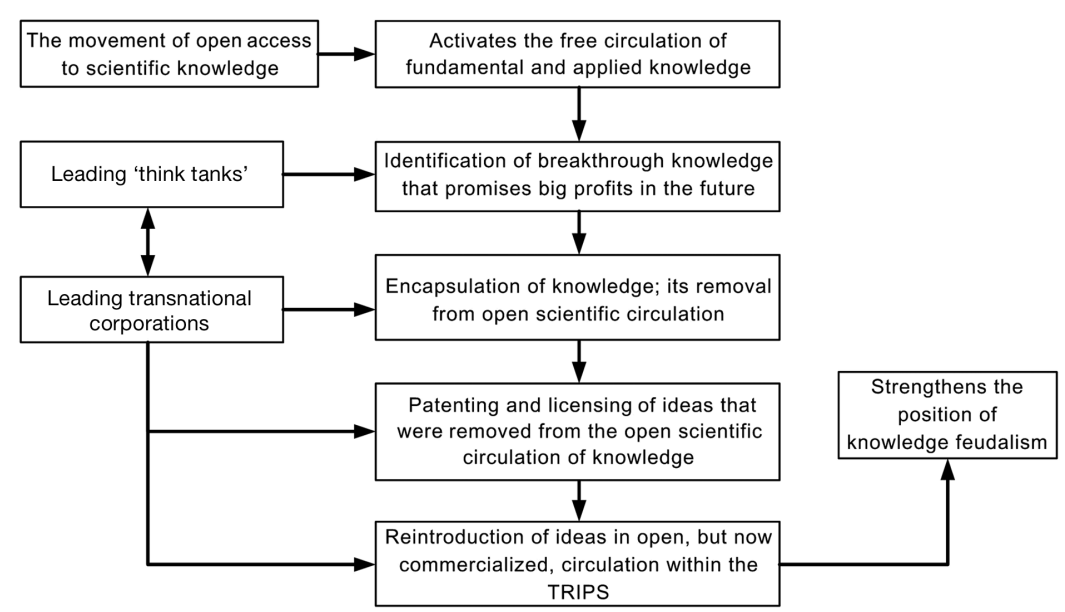

Fig. 4. The connection between open access to scientific knowledge and knowledge feudalism 
The book begins with a description of an interesting scene: a little girl is swinging on a swing in an unusual way - perpendicular to the normal direction. A few days later, her parents receive a letter from the Intellectual Property Enforcement Agency, informing them that this way of swinging was patented in 2002 by 'Play and Pay Co.', so the parents need to either buy a license or be punished.

This example shows how exercising intellectual property rights in the neo-liberal mainstream can lead to an absurdity. But how can we resist this? Some ideas that we suggest below may be of use.

(1) All developing countries must integrate and create strong regional economic groupings with all of their research and innovation systems integrated, while abandoning the 'publish or perish' race at the same time.

(2) Universities should create powerful networks including small and medium-sized enterprises in order to generate scientific breakthroughs without the participation of transnational companies (this is now being implemented within FP 7, 7th Framework Programme for Research and Technological Development). Such networks are of vital importance, as single universities, unlike transnational companies, which can afford to spend considerable funds on science, cannot generate knowledge for a new technological paradigm.

(3) It is necessary to change the existing system of patent law, so that vital inventions can become available for the public. Private capital cannot have an exclusive right to innovations and technologies, based substantially on the fundamental knowledge obtained earlier through use of public funds.

So, it is high time to reform the scientific world and its institutions. Why should we stick to the models that were designed at times so very different to those we live in today? Why should the neoliberal mainstream dominating in all sectors of economy and politics also set the rules of play in the scientific field? Everyone can see that a unipolar model of the world is defective, whereas the multipolar world with its variety is what we actually need for its sustainable development. Why do we not accept this as the basis for creating a sustainable global scientific system, so that we can abandon the unipolar Anglo-American model in science? How many more negative consequences in the neo-liberal scientific framework (Fig. 2) should there be before we give it up? Science should work for the prosperity of countries and the people living in them, rather than for enhancing multinational capital. Why then have more and more countries, many of which used to set the standard in science (e.g. Russia or France), become engaged in a race for publication under the slogan 'publish or perish'? This slogan should have been transformed long ago into 'publish best or do not publish at all', which, along with the principle of cultural and linguistic diversity in science and the Liquid Publication paradigm, could be used as the basis for sustainable development of both national and global scientific systems.

\section{A SUDDEN AND LARGE-SCALE BLOW TO THE 'PUBLISH OR PERISH' DOCTRINE IN 2012-2013}

The powerful Open Access movement, the Liquid Publications concept, the situation in China along with the San Francisco Declaration, proclaiming refusal from defective scientometric instruments in the current global crisis, led in our view to the year 2012 becoming a crucial moment in the fight against the neo-liberal doctrine 'publish or perish'. To prove this proposition, on the SCImago platform we have selected the 50 leading countries by the number of SCOPUS publications in 2013 and have studied their dynamics over the recent years. The findings can be seen in Table 2.

Table 2. Trends in the dynamics of SCOPUS publications for the world's leading countries in research

\begin{tabular}{ll} 
Trend in publication dynamics & Countries \\
\hline Stable growth of publications & Australia, Honking, Pakistan, Saudi Arabia, Turkey (Total: 5 countries) \\
$\begin{array}{l}\text { Slowdown in growth of } \\
\text { publications }\end{array}$ & $\begin{array}{l}\text { Brazil, Denmark, Egypt, India, Italy, China, Columbia, Malaysia, Mexico, Poland, Portu- } \\
\text { gal, Russia, Slovakia, Finland, Czech Republic, Chile, Sweden, South Africa, South }\end{array}$ \\
& Korea (Total: 19 countries) \\
$\begin{array}{l}\text { Decrease in publications } \\
\text { in 2012-2013 }\end{array}$ & $\begin{array}{l}\text { Austria, Argentina, Belgium, Bulgaria, Canada, Croatia, Great Britain, Hungary, } \\
\text { Germany, Greece, Israel, Iran, Ireland, Spain, The Netherlands, New Zealand, Norway, } \\
\text { Romania, Singapore, USA, Thailand, Taiwan, Ukraine, France, Switzerland, Japan } \\
\text { (Total: 26 countries) }\end{array}$
\end{tabular}


As we can see from the table, from the 50 global research leaders, only 5 countries demonstrated a stable growth in 2012-2013, while 26 countries witnessed various degrees of decline in publication numbers. Some examples of the dynamics of SCOPUS publications for selected countries can be seen in Fig. 5.

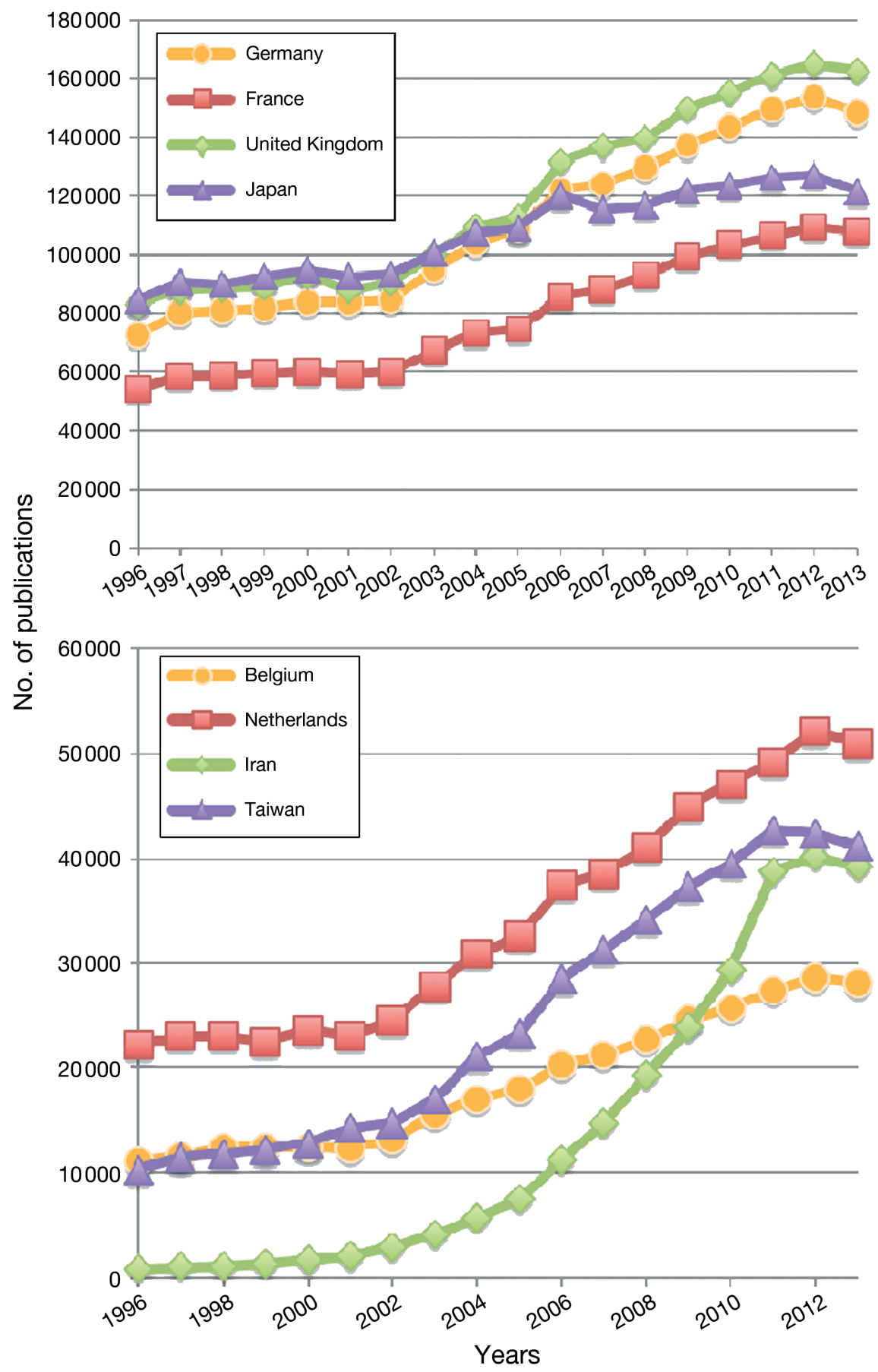

Fig. 5. Dynamics of the number of SCOPUS publications for selected countries from 1996 to 2013
We can assume that in most countries the governments have suddenly reduced their support of the publication activity of their scientists, or scientists themselves have lost interest in the publication race. Thus, the discontent with the 'publish or perish' doctrine that has been brewing in scientific communities around the world has come to light.

If we assume that the impact factor of journals in which scientists publish their articles will cease to be a criterion of scientists' career growth, then the publication race will disappear. That is why it is so important for the scientific community to have the final say on this issue. Even now, thanks to Open Access facilities, an interesting relevant article from a non-elite journal can in many cases be found, downloaded and cited even more successfully than a similar article from an elite journal. This situation has made a number of scientists place PDF files of their articles in Open Access repositories or send the manuscripts directly to Open Access journals.

All of the above makes us assume that the system of formal communications that has been in existence since 1665 will soon be substituted by another onesuch as the Liquid Publication concept — and then there will be no need to clutter up scientific space with worthless information and the quality of a paper will be assessed not by 2 or 3 reviewers, but rather by a relevant scientific community, as was stipulated by the founders of the concept. Then the 'publish or perish' motto will give way to new ones: 'publish best or do not publish at all' or 'publish best in order not to perish'.

Acknowledgements. This research was done according to the Government task of the Ministry of Education and Science of the Russian Federation for 2015, project code -516 . 


\section{LITERATURE CITED}

Balatsky E, Ekimova N (2012) The global university rankings: the problem of manipulation. J New Econ Assoc 13: 126-146

Berg RD (1987) Letters of Marshall McLuhan. Can J Commun 13:142-144. Available at www.cjc-online.ca/index. php/journal/article/download/471/377 (accessed 23 February 2015)

Coughlan S (2014) France plans elite top-10 mega-university. BBC News. 10.12.2014 Available at www.bbc.com/ news/business-30347441 (accessed 5 March 2015)

Drahos P, Braithwaite J (2002) Information feudalism: Who owns the knowledge economy? Earthscan Publications, London. Available at https://www.anu.edu.au/fellows/ pdrahos/books/Information\%20Feudalism.pdf (accessed 23 February 2015)

Franck G (1999) Scientific communication - a Vanity Fair? Science 286:53-55

Garfield E (1996) What is the primordial reference for the phrase 'Publish or Perish'? The Scientists 10:11-12. Available at www.garfield.library.upenn.edu/commentaries/tsv10\%2812\%29p11y19960610.pdf (accessed 23 February 2015)

Haider J, Bawden D (2006) Pairing information with poverty: traces of development discourses in LIS. New Libr World 107:371-385

Haider J, Bawden D (2007) Conceptions of 'information poverty' in LIS: a discourse analysis. J Doc 63:534-557

Haycock G, MacMillan R (2008) Thomson Reuters debuts amid global market jitters. Available at http://www. reuters.com/article/2008/04/18/industry-thomsonreuters-dc-idUSN1438977620080418\#r6fpduUjVA0Rjsjj.97 (accessed 5 July 2015)

Herb U (2010) Sociological implications of scientific publishing: Open Access, science, society, democracy, and the digital divide. First Monday 15:1 February 2010. Available at http://firstmonday.org/ojs/index.php/fm/article/ view/2599/2404 (accessed 23 February 2015)

Inozemtsev V (2014) Imitaziya rossijskoj nauki [Imitation of the Russian Science]. Moscow. Kommersant. 12.04.2014. Available at www.mk.ru/social/2014/05/12/imitatsiyarossiyskoy-nauki.html (accessed 5 March 2015)

Kiley R, Terry R (2006) Open access to the research literature: a funder's perspective. In: Jacobs $\mathrm{N}$ (ed) Open Access: key strategic, technical and economic aspects. Chandos, Oxford, p 101-109. Available at http://eprints. rclis.org/7531/1/Chapter_10_final.pdf (accessed 24 February 2015)

McGuigan GS, Russel RD (2008) The business of academic publishing: a strategic analysis of the academic journal publishing industry and its impact on the future of scholarly publishing. Electronic Journal of Academic and Special Librarianship 9. Available at http://southern librarianship.icaap.org/content/vo9no3/mcguigan_go1. html (accessed 23 November 2014)

Mirowski Ph (2011) Science-mart: privatizing American science. Harvard University Press. Available at www.hup. harvard.edu/catalog.php?isbn=9780674046467 (accessed 23 February 2015)

Monbiot G (2011) The lairds of learning. Guardian, 30 August 2011. Available at www.monbiot.com/2011/ 08/29/the-lairds-of-learning/ (accessed 23 February 2015)

Moskovkin VM (2011) Open access to scientific knowledge and feudalism knowledge: is there a connection? Webology 8. Available at www.webology.org/2011/v8n1/a83. html (accessed 23 February 2015)

Moskovkin VM (2012) A paradigm shift in the formal scientific communication. Universitates: nauka i prosvechenie [Science and education], 4:4-7 [in Russian]. Available at http://dspace.bsu.edu.ru/jspui/handle/123456789/4444 (accessed 13 May 2014)

Porter JR (1964) The scientific journals - 300th anniversary. Bacteriol Rev 28:210-230. www.researchgate.net/ publication/9362866_THE_SCIENTIFIC_JOURNAL300TH_ANNIVERSARY (accessed 1 July 2015)

Price DJD (1963) Little science, big science. New York: Columbia University Press. 119. Available at http:// datahub.io/dataset/de-solla-price-little-science-big-science (accessed 5 July 2015)

Qiu J (2010) Publish or perish in China. Nature 463:142-143

Research* $^{*}$ u (2010) New paradigm for scientific publication and peer review. Research*eu Results Supplement 27: 34-35. Available at ftp://ftp.cordis.europa.eu/pub/news/ research-eu/docs/researchsupplement27.pdf (accessed 23 February 2015)

Robinson D (2014) The mismeasure of higher education? The corrosive effect of university rankings. Ethics Sci Environ Polit 13:65-71

Scitext Cambridge (2000) A short history of science writing. Scitext Cambridge. available at www.scitext.com/history.php (accessed 2 July 2015)

Shank R (1962) Scientific and technical periodicals. Libr Trends 10:390-404. https://www.ideals.illinois.edu/handle/2142/5244 accessed July 1, 2015

Shao J, Shen H (2011) The outflow of academic papers from China: why has it happened and can it be stemmed? Learn Publ 24:95-97. Available at www.ingentaconnect. com/content/alpsp/lp/2011/00000024/00000002/art00003 ?crawler=true $\&$ mimetype $=$ application $/$ pdf $\quad($ accessed 23 February 2015)

Stergiou KI, Lessenich S (2014) On impact factor and university rankings: from birth to boycott. Ethics Sci Environ Polit 13:101-111

The Economist (2011) Of goats and headaches. The Economist, 26 May 2011. Available at http://www.economist. com/node/18744177 (accessed 15 December 2013).

Veblen Th (1918) The higher learning in America: a memorandum on the conduct of universities by business men. B. W. Huebsch, New York. Available at www. elegant-technology.com/resource/HI_LEARN.PDF (accessed February 23, 2015)

- Wallace ML, Lariviere V, Gingras Y (2012) A small world of citations? The influence of collaboration networks on citation practices. PLoS ONE 7 (3), e33339

Submitted: June 17, 2014; Accepted: September 18, 2015

Proofs received from author(s): January 16, 2016
Editorial responsibility: Konstantinos Stergiou,

Thessaloniki, Greece 